Sains Malaysiana 50(1)(2021): 135-149

http://dx.doi.org/10.17576/jsm-2021-5001-14

\title{
Preparation and Characterization of Copper, Iron, and Nickel Doped Titanium Dioxide Photocatalysts for Decolorization of Methylene Blue
}

\author{
(Penyediaan dan Pencirian Fotomangkin daripada Tembaga, Besi dan Nikel Titanium Dioksida untuk Penyahwarnaan \\ Metilena Biru)
}

JaWed QAderi, Che Rozid Mamat \& Aishah ABdul Jalil

\begin{abstract}
The visible-light response is a necessary condition for titanium dioxide ( $\mathrm{TiO}_{2}$ ) photocatalyst to function as a visible light active photocatalyst. This condition can be solved by investigation of the bandgaps and the optimization of doping levels of multivalency metal-doped $\mathrm{TiO}_{2}$. In this study, pure and $\mathrm{Cu}, \mathrm{Fe}$, and $\mathrm{Ni}$-doped $\mathrm{TiO}_{2}$ photocatalysts were prepared by the sol-gel method. The photocatalysts were characterized using XRD, FTIR, FESEM, EDX, $N_{2}$ physisorption, and UV-Vis spectrophotometry techniques. The XRD patterns of all pure $\mathrm{TiO}_{2}$ and $\mathrm{Cu} / \mathrm{TiO}, \mathrm{Fe} / \mathrm{TiO}$, and $\mathrm{Ni} / \mathrm{TiO}{ }_{2}$ samples showed the dominant structure of the anatase $\mathrm{TiO}_{2}$ phase. The presence of functional groups at the interface of $\mathrm{TiO}_{2}$ particles was showed by FTIR. The FESEM analysis showed that the particle size of the prepared samples was uniform with spherical morphology. EDX results showed that $\mathrm{TiO}$, has successfully incorporated $\mathrm{Cu}, \mathrm{Fe}$, and $\mathrm{Ni}$ metals onto its surface. The BET analysis showed that the specific surface area of the doped samples increased with the amount of doping. The optical properties of all samples were carried out using UV-DRS measurements and their obtained bandgap energies were in the range of 3.22 - $3.42 \mathrm{eV}$. The pure $\mathrm{TiO}_{2}$ displayed more than $98 \%$ and $97 \%$ decolorization rates for MB solution at the end of irradiation time of $5 \mathrm{~h}$ under UV and visible light, respectively. Among the doped samples, $3 \mathrm{~mol} \% \mathrm{Ni} / \mathrm{TiO}_{2}$ and $\mathrm{Cu} / \mathrm{TiO}_{2}$ demonstrated the highest photocatalytic activity (97.65\%) under UV light and $6 \mathrm{~mol} \% \mathrm{Ni} / \mathrm{TiO}$, under visible light for $\mathrm{MB}(96.86 \%)$ decolorization.
\end{abstract}

Keywords: $\mathrm{Cu} / \mathrm{TiO}_{2} ; \mathrm{Fe} / \mathrm{TiO}_{2}$; $\mathrm{Ni} / \mathrm{TiO}$; photocatalyst; sol-gel; titanium dioxide (TiO $)_{2}$

ABSTRAK

Tindak balas cahaya nampak adalah syarat penting fotomangkin titanium dioksida (TiO ${ }_{2}$ ) berfungsi sebagai fotomangkin cahaya tampak aktif. Keadaan ini boleh diselesaikan dengan penyelidikan jurang jalur dan pengoptimuman kandungan dopan logam pelbagai valensi dalam $\mathrm{TiO}_{2}$. Dalam kajian ini, fotomangkin TiO tulen dan yang didopkan dengan logam peralihan pada kala keempat iaitu, Cu, Fe, dan Ni, telah disediakan melalui kaedah sol-gel. Fotomangkin dicirikan menggunakan teknik XRD, FTIR, FESEM, EDX, $N_{2}$ dan spektrofotometri UVVis. Spektrum XRD bagi semua $\mathrm{TiO}_{2}$ tulen dan $\mathrm{Cu} / \mathrm{TiO}, \mathrm{Fe}_{2} \mathrm{TiO}_{2}$ dan $\mathrm{Ni} / \mathrm{TiO}{ }_{2}$ menunjukkan struktur dominan fasa anatase $\mathrm{TiO}_{2}$. Kehadiran ikatan kimia yang kuat antara permukaan zarah $\mathrm{TiO}_{2}$ telah dibuktikan oleh FTIR. Analisis FESEM mendedahkan bahawa saiz zarah sampel yang disediakan seragam dengan morfologi sfera. Keputusan EDX menunjukkan $\mathrm{TiO}_{2}$ telah berjaya didopkan dengan logam $\mathrm{Cu}$, Fe dan Ni di atas permukaannya. Analisis BET menunjukkan kawasan permukaan khusus sampel dopan meningkat dengan jumlah bahan dopan. Sifat optik kesemua sampel telah diuji menggunakan kaedah pengukuran UV-DRS dan tenaga jalur yang diperoleh berada dalam julat 3.22 - $3.42 \mathrm{eV}$. Fotomangkin $\mathrm{TiO}_{2}$ tulen menunjukkan lebih daripada 98\% dan 97\% kadar penguraian foto untuk MB pada penghujung masa penyinaran selama 5 jam di bawah sinaran UV dan cahaya nampak. Antara semua sampel TiO ${ }_{2}$ yang berdop, 3 mol\% $\mathrm{Ni} / \mathrm{TiO}_{2}$ dan $\mathrm{Cu} / \mathrm{TiO}_{2}$ menunjukkan aktiviti fotomangkin tertinggi (97.65\%) di bawah cahaya UV dan 6 mol\% $\mathrm{Ni} / \mathrm{TiO}_{2}$ di bawah cahaya tampak untuk $\mathrm{MB}(96.86 \%)$.

Kata kunci: $\mathrm{Cu} / \mathrm{TiO}_{2} ; \mathrm{Fe}_{\mathrm{TiO}}$; $\mathrm{Ni} / \mathrm{TiO}_{2}$; fotomangkin; sol-gel; titanium dioksida (TiO $)$

\section{INTRODUCTION}

In the last decade, photocatalysis using light irradiation, a safe and desirable technique, has attracted considerable considerations as it is carried out at low temperature, normal pressure, and without the need for high input energy (Shehzad et al. 2018). Because of its attractive 
properties, $\mathrm{TiO}_{2}$ is a widely used photocatalyst among all metal oxide semiconductors. Such properties include availability and affordability, strong charge transfer efficiency, protection and corrosion resistance, powerful oxidation properties, and easy tuning (Adekoya et. 2019). While $\mathrm{TiO}_{2}$ has several unique properties, its practical application is limited due to its high recombination charge rate, low quantum yield, and high bandgap energy (3.20 eV for anatase) (Edelmannová et al. 2018); so $\mathrm{TiO}_{2}$ has only UV light activity (wavelength of less than 380 $\mathrm{nm})$. It means that in this region of the spectrum, $\mathrm{TiO}_{2}$ is mostly inactive under visible light, which is the largest part of the solar spectrum (Adekoya et al. 2019). Doping with small amounts of transition metals is the best way to improve the photocatalytic performance among the various modifications of $\mathrm{TiO}_{2}$ usually applied. The advantages of metal doping include a decrease in the frequency of electron-hole pairs of recombination because of trapping of electrons by metal ions and an increase in the wavelength response to the visible region (Ali et al. 2017).

Nowadays, huge amounts of artificial and organic dyes are manufactured and consumed every day for coloring purposes in different sectors worldwide. Trace dye levels in effluent streams pose a significant threat to plants, livestock, atmosphere, and human health because of their poisonous and non-biodegradable existence (KerkezKuyumcu et al. 2015). Among all the dyes, methylene blue (MB) which is a cationic dye, has been widely employed for dyeing cotton, wool, and silk. The risk of this dye being present in wastewater can arise from the effect of the burns to the eye, nausea, vomiting, and diarrhea (Salehi et al. 2012). Elimination of this dye from wastewater is regarded as a major environmental issue. Several methods have been suggested including biodegradation, coagulation, adsorption, and removal of membranes for the extraction of dye from wastewater (Ahmad \& Puasa 2007; Derudi et al. 2007; Mo et al. 2008). The traditional techniques used are not damaging as a whole, they just convert water pollution from one phase to another. Heterogeneous photocatalysis has become a successful and environmental friendly alternative for the degradation of toxic organic dye materials, as this method decomposes dyes and colorants into harmless carbon dioxide and water molecules (Rauf \& Ashraf 2009; Soutsas et al. 2010).

The main goal of this study was to prepare and improve a range of simple, stable, and efficient pure and doped $\mathrm{TiO}_{2}$ photocatalysts with three different transition metals of the fourth period namely, copper $(\mathrm{Cu})$, iron $(\mathrm{Fe})$, and nickel $(\mathrm{Ni})$ by the sol-gel method. Among various elements doped so far into $\mathrm{TiO}_{2}, \mathrm{Cu}, \mathrm{Fe}$, and Ni have been widely studied and considered to be important owing to the narrow bandgap energies and their high light absorption capacities. The $\mathrm{Cu}, \mathrm{Fe}$, and $\mathrm{Ni}$ doping have been found to replace certain $\mathrm{Ti}^{4+}$ ions in substitutional sites of $\mathrm{TiO}_{2}$, and to cause the segregation and incorporation of $\mathrm{Cu}, \mathrm{Fe}$, and $\mathrm{Ni}$ on the surface of, and into the interstitial sites of $\mathrm{TiO}_{2}$. The concentration of each metal dopants was predetermined to be 3,6, and $9 \mathrm{~mol} \%$. Despite a large number of studies have been carried out on these $\mathrm{Cu}, \mathrm{Fe}$, and $\mathrm{Ni}$-doped $\mathrm{TiO}_{2}$ systems, many aspects with regard to the role of elements species with multivalent states including $\mathrm{Cu}^{2+}, \mathrm{Fe}^{3+}$, and $\mathrm{Ni}^{2+}$ in the photocatalytic reaction remain unclear. The effects of adding three successive transition metal elements, $\mathrm{Cu}$, $\mathrm{Fe}$, and $\mathrm{Ni}$ as dopants were studied to enhance the $\mathrm{TiO}_{2}$ photoresponse to the visible light spectrum and to increase the photocatalytic performance of the host semiconductor photocatalyst and the effects of the surface species on the photocatalytic activity were investigated by means of X-ray diffraction (XRD), Fourier transform infrared (FTIR), nitrogen physiosorption, Field Emission Scanning Electron Microscope (FESEM), Energy Dispersive X-ray (EDX) and diffuse reflectance spectra UV-Vis (DRS) spectroscopy. MB from the thiazine group of dyes was taken as the target pollutant to examine the effect of the structure of the dye on the photocatalytic decolorization process and to assess the photocatalytic efficiency of the photocatalysts under UV-Vis light irradiation.

\section{MATERIALS AND METHODS}

\section{PREPARATION OF THE PHOTOCATALYSTS}

The preparation of $\mathrm{Cu}, \mathrm{Fe}$, and $\mathrm{Ni}$-doped $\mathrm{TiO}_{2}$ photocatalysts with different concentrations of $\mathrm{Cu}, \mathrm{Fe}$, and $\mathrm{Ni}(3,6$, and $9 \mathrm{~mol} \%$ ) was carried out using the sol-gel technique adopted from Rajamannan et al. (2014b) using titanium tetraisopropoxide (TTIP, purity $97 \%$, Aldrich). The precursors for $\mathrm{Cu}, \mathrm{Fe}$, and Ni metals were $\mathrm{Cu}\left(\mathrm{CH}_{3} \mathrm{COO}\right)_{2}$ (purity $\left.98 \%, \mathrm{GCE}\right), \mathrm{FeCl}_{3}$ anhydrous (purity $98 \%, \mathrm{GCE}$ ), and $\mathrm{Ni}\left(\mathrm{NO}_{3}\right)_{2} \cdot 6 \mathrm{H}_{2} \mathrm{O}$ (purity $96 \%$, GCE), respectively, and isopropanol and water were used as the solvents for the precursors. For the synthesis of $\mathrm{Cu}$, $\mathrm{Fe}$, and $\mathrm{Ni}$-doped $\mathrm{TiO}_{2}$ samples, $90 \mathrm{~mL}$ of isopropanol and the exact quantities of $\mathrm{Cu}\left(\mathrm{CH}_{3} \mathrm{COO}\right)_{2}, \mathrm{FeCl}_{3}$, and $\mathrm{Ni}\left(\mathrm{NO}_{3}\right)_{2} \cdot 6 \mathrm{H}_{2} \mathrm{O}$ were dissolved in $10 \mathrm{~mL}$ of distilled water, respectively. The entire mixture of isopropanol and metals precursors dissolved in distilled water was continuously stirred at room temperature to obtain a homogenous solution and $10 \mathrm{~mL}$ of TTIP was added dropwise to the above mixture with mechanical stirring. The whole mixture of TTIP and isopropanol was continuously stirred using a magnetic stirrer for $5 \mathrm{~h}$. The stirred solution was filtered using Whatman filter paper and washed several times using deionized water to remove the impurities. The precipitates were dried at $80{ }^{\circ} \mathrm{C}$ for $5 \mathrm{~h}$ to evaporate the organic residues and other impurities. In order to obtain the desired anatase phase of pure $\mathrm{TiO}_{2}$, the dried 
powders were calcined at $500{ }^{\circ} \mathrm{C}$ for $2 \mathrm{~h}$. Finally, the calcined powders of $\mathrm{Cu}, \mathrm{Fe}$, and $\mathrm{Ni}$-doped $\mathrm{TiO}_{2}$ samples were grinded in an agate mortar to avoid agglomeration. In turn, pure $\mathrm{TiO}_{2}$ reference was synthesised using the same procedure without the addition of metal precursors in order to compare the results obtained.

\section{CHARACTERIZATION}

Various analytical characterization techniques were used to determine the physicochemical properties such as structure, crystalline phase, composition, distribution of elements within the material, organic and inorganic bands of functional groups, morphology and elemental composition, surface area, absorption region of each photocatalyst in the spectrum and the bandgap energy, and the percentage decolorization, respectively. In all cases, sample of pure $\mathrm{TiO}_{2}$ were also measured for blank comparison with the results obtained.

The identification for crystallinity of the photocatalysts was determined using Radaku SmartLab $\mathrm{X}$-ray diffractometer (XRD) equipped with $\mathrm{CuK} \alpha(\lambda=$ $0.15406 \mathrm{~nm}$ ) radiation operating at $40 \mathrm{kV}$ with $30 \mathrm{~mA}$. The analysis was recorded in the range $2 \theta=20-80^{\circ}$ at room temperature with the increment $2^{\circ} \mathrm{min}^{-1}$. The Fourier transform infrared (FTIR) spectra were recorded using PerkinElmer Spectrometer with resolution of $8 \mathrm{~cm}^{-1}$ in the range of $4000-400 \mathrm{~cm}^{-1}$ at $\mathrm{KBr}$ phase. BET surface area was measured by nitrogen physisorption at $77 \mathrm{~K}$ using NOVA touch 4LX (Quantachrome Instruments, USA) apparatus. Prior to analysis, the photocatalysts were outgassed under vacuum at ambient temperature for $12 \mathrm{~h}$. The surface morphology and elemental composition of the samples were investigated by field emission scanning electron microscope (FESEM) CROSSBEAM 340 ZEISS with GEMINI column and energy dispersive X-ray analysis using OXFORD INSTRUMENTS X-Max ${ }^{\mathrm{N}}$ system. The diffuse reflectance spectra UV-Vis (DRS) was performed at room temperature using UV-3600 Plus Shimadzu spectrophotometer to analyse the absorbance spectra of the photocatalysts using $\mathrm{BaSO}_{4}$ as reference in the wavelength range of $\lambda=200-800 \mathrm{~nm}$.

\section{PHOTOCATALYTIC ACTIVITY TESTS}

The photocatalytic tests were performed in an aqueous solution utilizing MB dye as the model pollutant. An amount of $0.1 \mathrm{~g}$ of the prepared pure and $\mathrm{Cu}, \mathrm{Fe}$, and Ni-doped $\mathrm{TiO}_{2}$ photocatalysts were mixed into $100 \mathrm{~mL}$ aqueous $2.5 \mathrm{mg} / \mathrm{L} \mathrm{MB}$ solution to test the photocatalytic performance of each synthesised photocatalyst. The homemade box and a glass beaker of $250 \mathrm{~mL}$ in volume were used as the photoreactor for UV and visible light photocatalysis. For both the UV and visible light photocatalysis, two irradiation sources by an ultraviolet lamp with a wavelength peak at $365 \mathrm{~nm}$ and $90 \mathrm{~W}$ power, and a commercial halogen lamp PANASONIC with 25 $\mathrm{W}$ power were provided, respectively. For achieving the adsorption-desorption equilibrium before illumination by UV/Vis lamps, the solution was stirred in the dark using a magnetic stirrer for $1.5 \mathrm{~h}$ for each reaction. During the light irradiation, the reaction mixture was continuously stirred on a magnetic stirrer. The decolorization of dye was monitored using a UV-Vis spectrometer at $\lambda_{\max }=664$ $\mathrm{nm}$. The decolorization percentage (D) was determined by (1), as given:

$$
D(\%)=\frac{C_{\mathrm{o}}-C}{C_{\mathrm{o}}} \times 100 \%
$$

where $C_{\mathrm{o}}$ is initial concentrations of MB obtained before illumination and $C$ is final concentrations at particular time (t), respectively. The photocatalytic tests were performed at room temperature and atmospheric pressure.

\section{RESULTS AND DISCUSSION}

\section{X-RAY DIFFRACTION ANALYSIS}

X-ray diffraction (XRD) was used to determine the phase, crystallinity, and structural properties of the photocatalysts. XRD analysis was conducted to clarify the presence of the initial bulk $\mathrm{TiO}_{2}$ phases after calcination and the development of various crystalline $\mathrm{TiO}_{2}$ phases induced by the various metal dopants mentioned previously. Figure 1 shows the wide-angle XRD patterns of pure $\mathrm{TiO}_{2}$ and $\mathrm{TiO}_{2}$ doped with 3, 6, and $9 \mathrm{~mol} \%$ of each of $\mathrm{Cu}, \mathrm{Fe}$, and $\mathrm{Ni}$ metals. The XRD patterns of pure $\mathrm{TiO}_{2}$ and $\mathrm{Cu}, \mathrm{Fe}$, and $\mathrm{Ni}$-doped $\mathrm{TiO}_{2}$ samples showed the dominant structure of anatase phase of the $\mathrm{TiO}_{2}$ by the presence of crystalline peaks at $2 \theta$ of $25.3^{\circ}, 37.9^{\circ}, 48.0^{\circ}$, $53.9^{\circ}, 55.0^{\circ}, 62.8^{\circ}, 68.8^{\circ}, 70.2^{\circ}$, and $75.1^{\circ}$, reflecting the indices of (101), (004), (200), (105), (211), (204), (116), (220), and (215) tetragonal $\mathrm{TiO}_{2}$ anatase phase planes, respectively (Krishnakumar et al. 2016). Peak related to precursors was not detected.

In general, the peaks for $\mathrm{Cu}$-doped $\mathrm{TiO}_{2}, \mathrm{Fe}$-doped $\mathrm{TiO}_{2}$, and Ni-doped $\mathrm{TiO}_{2}$ samples almost matched those of pure $\mathrm{TiO}_{2}$. No deviation of the peak position was observed with the changes in dopant concentration. This clearly indicates that dopant ions occupied the substitutional sites of $\mathrm{Ti}^{4+}$ without having distortion of the host lattice (Kavitha et al. 2016). The explanation for stabilizing $\mathrm{TiO}_{2}$ in anatase process after doping with $\mathrm{Ni}$ at lower levels was due to the nearly identical $\mathrm{Cu}^{2+}, \mathrm{Fe}^{3+}$, and $\mathrm{Ni}^{2+}$ ionic radii $(0.72,0.69$, and $0.72 \AA$, respectively) to that of $\mathrm{Ti}^{4+}(0.68 \AA)$, which was found to replace some portion of $\mathrm{Ti}^{4+}$ ions in $\mathrm{TiO}_{2}$ lattice (Ganesh et al. 2012; Sahoo \& Gupta 2015). Furthermore, the formation of any 
crystalline phase of $\mathrm{Cu}, \mathrm{Fe}$, and $\mathrm{Ni}$ species was not shown in XRD and the spectrum did not show any characteristic peak attributed to transition metal oxides. These results were similar with the findings obtained by Aguilar et al. (2013) and Sahoo and Gupta (2015).

The average crystallite size of all the synthesised pure and doped $\mathrm{TiO}_{2}$ photocatalysts was obtained from the full width at half maximum (FWHM) of the most intense (101), (004), and (204) XRD peaks by using the following Scherrer equation:

$$
d(n m)=\frac{0.9 \lambda}{\beta \cos \theta}
$$

where $d$ is the average crystallite size; $\lambda$ is the X-ray wavelength used in XRD analysis which is equal to $0.15406 \mathrm{~nm} ; \beta$ is the full-width at half-maximum; and $\theta$ is the angle of diffraction for the broadening peak (Aguilar et al. 2013). Table 1 shows the average crystallite size of all the prepared samples. The XRD results obtained suggest that the size of the crystallite and the crystallization of the samples both decreased as the concentration of $\mathrm{Cu}, \mathrm{Fe}$, and Ni metal dopants in pure $\mathrm{TiO}_{2}$ increased. The decrease in the size of crystallite with an increase in doping shows that $\mathrm{Cu}, \mathrm{Fe}$, and $\mathrm{Ni}$ doping inhibited $\mathrm{TiO}_{2}$ crystallite growth. These findings conclude that copper, iron, and nickel affect the growth of crystallite during synthesis, showing that the above-mentioned metals have a great potential as doping agents (Aguilar et al. 2013; Nankya \& Kim 2016).

\section{NITROGEN PHYSISORPTION ANALYSIS}

Nitrogen physisorption analysis was used to calculate the BET surface area of the photocatalysts. Table 1 summarizes the results obtained from the calculations. The addition of dopants to the host $\mathrm{TiO}_{2}$ photocatalyst was observed to result in a larger surface area with the exception of $3 \mathrm{~mol} \% \mathrm{Cu}$-doped $\mathrm{TiO}_{2}$ sample. This was not in agreement with the fact that crystallite sizes decreased when the contents of $\mathrm{Cu}, \mathrm{Fe}$, and $\mathrm{Ni}$ increased. The reduction in crystallite size should lead to a greater specific surface area ( $\mathrm{Li}$ et al. 2008; Vargas et al. 2015). The increase in the surface area of the doped samples could be due to the fact that metal ions supply additional nucleation sites during the precipitation and subsequent calcination steps. Unfortunately, it was not the case for 3 $\mathrm{mol} \% \mathrm{Cu} / \mathrm{TiO}_{2}$ as the total surface area was even lower $\left(31.13 \mathrm{~m}^{2} / \mathrm{g}\right)$ compared to that of pure $\mathrm{TiO}_{2}\left(48.08 \mathrm{~m}^{2} / \mathrm{g}\right)$. This might be due to the actual loading of $\mathrm{Cu}$ was so low in $3 \mathrm{~mol} \% \mathrm{Cu}$-doped $\mathrm{TiO}_{2}$ that $\mathrm{Cu}$ metal ions could not form nucleation centres in the skeletal structure of $\mathrm{TiO}_{2}$ and could also be due to the pores blocked by copper species (Kerkez-kuyumcu et al. 2015).
FOURIER TRANSFORM INFRARED SPECTROSCOPY

The Fourier transform infrared (FTIR) spectroscopy provides evidence of the functional groups in $\mathrm{TiO}_{2}$ photocatalysts. The FTIR spectra of pure and $\mathrm{Cu}, \mathrm{Fe}$, and Ni-doped $\mathrm{TiO}_{2}$ photocatalysts are shown in Figure 2. The peaks at $3368,3230,3400,3393,3369$, and $3214 \mathrm{~cm}^{-1}$ represent the existence of surface $\mathrm{OH}$ groups and $\mathrm{H}_{2} \mathrm{O}$ molecules adsorbed on the surface and in the interlayer space (Kavitha et al. 2016). The peaks in between 2921 and $2853 \mathrm{~cm}^{-1}$ are assigned to $\mathrm{C}-\mathrm{H}$ stretching vibrations of alkane groups. The alkane groups come from isopropanol and TTIP that are used in the synthesis process (Guo et al. 2007). The peaks at 1628, 1625, and $1621 \mathrm{~cm}^{-1}$ correspond to the stretching vibrations of $\mathrm{OH}$ groups, which are slowly decreasing with increasing the metal concentration in host $\mathrm{TiO}_{2}$. The $\mathrm{OH}$ groups existing on the surface of $\mathrm{TiO}_{2}$ enhance the photocatalytic performance of the photocatalysts due to $\mathrm{OH}$ groups serving as the main scavenger of the photogenerated charge carrier (Ali et al. 2017). Moreover, the wide absorption band from 500 to $1000 \mathrm{~cm}^{-1}$ corresponds to the vibration absorption of the Ti-O-Ti linkages in the $\mathrm{TiO}_{2}$ molecules. The increase in metal concentrations could shift the Ti-O-Ti band to the lower wavenumbers and sharpening of the band and this is mainly because of the enhancement in crystallite size of the powders (Rajamannan et al. 2014a). In summary, the presence of strong functional groups at the interface of $\mathrm{TiO}_{2}$ photocatalyst was showed from FTIR results in pure and $\mathrm{TiO}_{2}$ doped photocatalysts. No peak for the precursors were observed in FTIR spectra.

\section{FIELD EMISSION SCANNING ELECTRON MICROSCOPY}

The morphology of the synthesised pure and doped $\mathrm{TiO}_{2}$ photocatalysts was studied using Field Emission Scanning Electron Microscopy (FESEM) analysis. Figure 3 shows the FESEM images of pure and $\mathrm{Cu}, \mathrm{Fe}$, and Ni-doped $\mathrm{TiO}_{2}$ photocatalysts. The pure $\mathrm{TiO}_{2}$ powder shows irregular small granular clusters. By incorporating the dopant in the $\mathrm{TiO}_{2}$ structure, the morphology and particle size of the photocatalyst change along with the increasing of $\mathrm{Cu}, \mathrm{Fe}$, and $\mathrm{Ni}$ concentrations. Figure 3 clearly shows the difference in size and morphology after doping with $\mathrm{TiO}_{2}$. It is clearly observed that the doped $\mathrm{TiO}_{2}$ photocatalysts depicted uniform distribution with irregular size spherical morphologies agglomeration which increased significantly with increasing amount of $\mathrm{Ni}$ ions in the host $\mathrm{TiO}_{2}$ and the variability is finely tuned with increasing concentration of dopants (Sood et al. 2015). Moreover, the particle size was small as a result of calcination and the increase in agglomeration between metals and $\mathrm{TiO}_{2}$ particles, which also indicates that metal doping can suppress the growth of $\mathrm{TiO}_{2}$ particles. These 
results are similar with the findings obtained by Nankya and Kim (2016) and Sakthivel and Jagannathan (2017). When metal ions doped into $\mathrm{TiO}_{2}$ lattice, they preferred to stay in grain boundary regions or on the particle surface to inhibit $\mathrm{TiO}_{2}$ crystal growth (Yang et al. 2015).

In addition, the elemental composition analysis of pure $\mathrm{TiO}_{2}$ and $\mathrm{Cu}, \mathrm{Fe}$, and $\mathrm{Ni}$-doped $\mathrm{TiO}_{2}$ powders with 3, 6 , and $9 \mathrm{~mol} \%$ metal concentration in terms of mass $\%$ and atomic $\%$, were performed using energy dispersive $\mathrm{X}$-ray analysis (EDX) and the results are shown in Figure 4. The intense peaks in pure $\mathrm{TiO}_{2}$ are associated with $\mathrm{O}$ (29.5\%) and $\mathrm{Ti}(29.5 \%)$ elements. The measured mass $\%$ for $\mathrm{Cu}$ are around $1.9,4.6$ and $6.6 \%$ for 3, 6 , and $9 \mathrm{~mol} \%$ $\mathrm{Cu} / \mathrm{TiO}_{2}, 1.9,1.5$, and $18.3 \%$ for $\mathrm{Fe}$ in 3,6 , and $9 \mathrm{~mol} \%$ $\mathrm{Fe} / \mathrm{TiO}_{2}$, and $1.0,0.9$, and $1.6 \%$ for $\mathrm{Ni}$ in 3,6 , and 9 $\mathrm{mol} \% \mathrm{Ni} / \mathrm{TiO}_{2}$, respectively. The mass $\%$ and atomic $\%$ of the substances are tabulated in their respective images in Figure 4. The obtained results showed that presence of dopant is increased corresponding to loading of $\mathrm{Cu}$, $\mathrm{Fe}$, and $\mathrm{Ni}$ concentrations. Moreover, no residual acetate, chloride, nitrate, and other impurities presented in all samples.

\section{UV-VIS DIFFUSE REFLECTANCE SPECTROSCOPY ANALYSIS}

UV-Vis Diffuse Reflectance Spectroscopy (DRS) was performed to study the optical absorption characteristics of the prepared samples. The UV-Vis absorbance spectra of pure and $\mathrm{Cu}, \mathrm{Fe}$, and $\mathrm{Ni}$-doped $\mathrm{TiO}_{2}$ are shown in Figure 5. The $\mathrm{TiO}_{2}$ photocatalyst showed an intense absorption in the UV region and as absorption edge of $\mathrm{TiO}_{2}$ can be easily discerned. $\mathrm{TiO}_{2}$ showed strong absorption between 200 and $390 \mathrm{~nm}$, attributed to the photon energy of 3.24 $\mathrm{eV}$, which is typical and identity of $\mathrm{TiO}_{2}$. Upon $\mathrm{Cu}, \mathrm{Fe}$, and $\mathrm{Ni}$ doping, there was an enhancement of the optical absorption properties which gives a significant right shift in the absorption spectra towards longer wavelengths. The doped samples showed remarkable absorbance in the region of $400-800 \mathrm{~nm}$, gradually demonstrating their strong visible light absorbance ability as compared to the pure $\mathrm{TiO}_{2}$ (Singla et al. 2015). Furthermore, parallel increase in light absorbance with the increase in metal-doping concentration was also seen (Thu et al. 2016). Incorporation of $\mathrm{Ni}^{2+}$ ions into $\mathrm{TiO}_{2}$ lattice shifted the fundamental absorption edge towards the longer wavelength. Since Ni-doped $\mathrm{TiO}_{2}$ can absorb light in a wider range of wavelengths and utilize more light energy than pure $\mathrm{TiO}_{2}$, a higher photocatalytic activity should be expected to Ni-doped $\mathrm{TiO}_{2}$ photocatalysts. These results suggest that metal-doping certainly causing absorbance of visible light by $\mathrm{TiO}_{2}$, enhancing light harvesting in both UV and visible light regions (Ganesh et al. 2012; Nankya \& Kim 2016; Su et al. 2007).
The direct bandgap energies for all photocatalysts were estimated using (3) by extrapolating the linear region of the spectra to $\alpha=0$ of a plot of $(\alpha h v)^{2}$ (Tauc plot) versus $(h v)$ as shown in Figure 6.

$$
(\alpha h v)^{1 / n}=A\left(h v-E_{g}\right)
$$

where $E_{g}$ is the bandgap energy; $h$ is Planck's constant; $v$ is the frequency of vibration; $h v$ is the photon energy; $A$ is a proportional constant; $\alpha$ is the absorption coefficient; and $n$ denotes the nature of the transition (Kerkez \& Boz 2014). Depending on the nature of transition, $n$ takes different values: For direct allowed transition $n=1 / 2$, for indirect allowed transition $n=2$, for direct forbidden transition $n=3 / 2$, for indirect forbidden transition $n$ $=3$. Since the direct allowed transition is used in this experiment, $n=1 / 2$ is used for the samples. The pure $\mathrm{TiO}$, sample (Figure 5) shows absorption at around 383 $\mathrm{nm}(3.24 \mathrm{eV})$ (i.e. in the UV range) which occurred due to the charge transfer from the VB mainly formed by $2 p$ orbitals of the oxide anions to the $\mathrm{CB}$ mainly formed by $3 d t_{2 g}$ orbitals of the $\mathrm{Ti}^{4+}$ cations (Venkatachalam et al. 2007). The estimated direct bandgap values of all samples shown in Table 2 are very close to the reported direct bandgap values for anatase. With the increase of $\mathrm{Cu}, \mathrm{Fe}$, and $\mathrm{Ni}$ concentrations, the bandgap energy of the $\mathrm{TiO}_{2}$ photocatalyst increased systematically. This can be attributed to the introduction of new electron states in the band structure of $\mathrm{TiO}_{2}$ upon $\mathrm{Cu}, \mathrm{Fe}$, and $\mathrm{Ni}$ doping $(\mathrm{Hu}$ et al. 2016; Manzoor et al. 2018). Any further increase in dopant concentration, the bandgap decreased. As can be observed from the trend, the bandgap value for $9 \mathrm{~mol} \% \mathrm{Ni}$ doped $\mathrm{TiO}_{2}$ is smaller $(3.22 \mathrm{eV})$ than that of pure $\mathrm{TiO}_{2}$. This trend is inconsistent with XRD results, where crystallite size initially decreased with doping and increased with an increasing amount of $\mathrm{Cu}, \mathrm{Fe}$, and $\mathrm{Ni}$ as well as $\mathrm{TiO}_{2}$. The absorption edge wavelength of all prepared samples are shown in Table 2. At the same time on a higher level of doping ( 6 and $9 \mathrm{~mol} \%$ ) in addition to UV band, visible bands are also predicted. These bands are positioned at the range of 400 to $500 \mathrm{~nm}$ for 6 and 9 mol\% doping amounts of $\mathrm{Cu}, \mathrm{Fe}$, and $\mathrm{Ni}$ metals (Rajamannan et al. 2014a, 2014b). However, in order to further enhance the photocatalytic activity, good interaction of $\mathrm{Cu}, \mathrm{Fe}$, and $\mathrm{Ni}$ with $\mathrm{TiO}_{2}$ is required which could be confirmed by the FESEM images.

\section{PHOTOCATALYTIC DECOLORIZATION OF METHYLENE BLUE}

In this study, the photocatalytic activities of the prepared pure and $\mathrm{Cu}, \mathrm{Fe}$, and $\mathrm{Ni}$-doped $\mathrm{TiO}_{2}$ photocatalysts with different concentrations of metals were tested by the decolorization of MB under both UV and visible light 
using homemade photoreactors. MB was selected because of its strong adsorption to metal oxide surfaces, welldefined optical absorption, and good resistance to light degradation (Jothibas et al. 2018). The photocatalytic experiments were carried out at an initial $\mathrm{pH}$ of 7.0 (Nakhate et al. 2010). The results of the photocatalytic decolorization of MB solution under UV and visible light irradiation in the presence of pure $\mathrm{TiO}_{2}$ are shown in Figures 7 and 8, respectively. It is clear from the figure, with UV irradiation, pure $\mathrm{TiO}_{2}$ photocatalyst exhibited higher photocatalytic activity than using visible light irradiation in decolorizing the MB solution. The photocatalytic decolorization of MB solution significantly increased with increasing the irradiation time. The pure $\mathrm{TiO}_{2}$ photocatalyst displayed more than 98 and $97 \%$ decolorization rates for MB solution at the end of irradiation time of $5 \mathrm{~h}$ under UV and visible light, respectively. In a recent study, Zhang et al. (2015) studied the decolorization of MB solution using $\mathrm{TiO}_{2}$ Degussa P25 and the process resulted in approximately $45 \%$ activity under visible light after $5 \mathrm{~h}$ of irradiation for the decolorization of MB. In another study by Kerkez-Kuyumcu et al. (2015), the pure $\mathrm{TiO}_{2}$ prepared by a modified precipitation method showed a $44.18 \%$ decolorization rate for MB solution under visible light at the end of $5 \mathrm{~h}$. Such results show that the pure $\mathrm{TiO}_{2}$ prepared in this study using the sol-gel method has comparable levels of activity with the commercial $\mathrm{TiO}_{2}$ Degussa P25 and $\mathrm{TiO}_{2}$ prepared using a modified precipitation process. The difference in photocatalytic activity of pure $\mathrm{TiO}_{2}$ under UV and visible light is very clear phenomenon, UV rays from the sunlight is less than $5 \%$ outdoor with little intensity (Inturi et al. 2014), the visible light employed for this study could be equate to sunlight, thus, the intensity of the UV content in the visible light is small.

In addition, as $\mathrm{TiO}_{2}$ particles absorb the light corresponding to their bandgap energy, an electron is excited from the valence band (VB) to the $\mathrm{TiO}_{2}$ conduction band $(\mathrm{CB})$, creating a separation of the electron-hole charges as shown in (4) in the following:

$$
\mathrm{TiO}_{2}+h v(\lambda<390 \mathrm{~nm}) \rightarrow \mathrm{e}^{-}+h^{+}
$$

The charges can then react with the adsorbed oxygen and hydroxyl surface groups, creating reactive oxygen species that react with organic compounds resulting in the total decomposition of those compounds. The lifetime of electrons and holes must be long enough for any photocatalytic reaction to allow them to enter the photocatalyst's surface. Adding transition metal ions creates new trapping sites that influence the lifespan of the charge carriers. Once $\mathrm{TiO}_{2}$ is doped with a transition metal, the photogenerated electrons in titanium are passed to the metal site $\mathrm{CB}$, which serves as traps for the photogenerated electrons, increases the lifetime of the electron-hole pairs and increases the likelihood of reactions between the electron-hole pairs and the reactive oxygen species (Kerkez \& Boz 2014). In this work, the visible light provided sufficient energy for the electrons to move from the VB to the $\mathrm{CB}$ and the $\mathrm{Cu}, \mathrm{Fe}$, and Ni dopants, served as an intermediate level of visible light electron excitation for MB decolorization purposes.

It is seen that the $\mathrm{Cu}$-doped $\mathrm{TiO}_{2}$ with $\mathrm{Cu}$ content of $3 \mathrm{~mol} \%$ showed improved photocatalytic performance of 97.65 and $90 \%$ under UV and visible light shown in Figures 7(a) and 8(a), respectively. When the content of $\mathrm{Cu}$ doping reached to 6 and $9 \mathrm{~mol} \%$, the photocatalytic performance decreased to the lowest level of 89 and $81.4 \%$ under UV light and 62.4 and $55.7 \%$ under visible light at the end of irradiation time of $5 \mathrm{~h}$, respectively, as compared to pure $\mathrm{TiO}_{2}$ (Yang et al. 2015). The photocatalytic decolorization rate of MB as a function of time on 3,6, and $9 \mathrm{~mol} \% \mathrm{Fe}$-doped $\mathrm{TiO}_{2}$ samples is given in Figures 7(b) and 8(b) under UV and visible light, respectively. It could be seen that the decolorization percentage is higher for pure $\mathrm{TiO}_{2}$ under both UV and visible light rather than $\mathrm{Fe}$-doped $\mathrm{TiO}_{2}$ photocatalysts. The decolorization percentages were $96.86,94.9,92.38 \%$ for 3,6 , and 9 $\mathrm{mol} \% \mathrm{Fe} / \mathrm{TiO}$, under UV light, respectively. The Fe-doped $\mathrm{TiO}_{2}$ samples had less photocatalytic efficiency than pure $\mathrm{TiO}_{2}$ under visible light irradiation. The decolorization rate were $84.34,60$, and $62.42 \%$ at the end of $5 \mathrm{~h}$ visible light irradiation for 3, 6, and $9 \mathrm{~mol} \% \mathrm{Fe}$-doped $\mathrm{TiO}_{2}$ photocatalysts, respectively. This showed that the photocatalytic activity of the $\mathrm{Fe}$-doped $\mathrm{TiO}_{2}$ photocatalysts decreased with increasing the Fe concentration (Ali et al. 2017; Li et al. 2008).

The photocatalytic efficiency of Ni-doped $\mathrm{TiO}_{2}$ samples is shown in Figures 7(c) and 8(c). It can be seen that among all $\mathrm{Ni}$-doped $\mathrm{TiO}_{2}$ photocatalysts, $3 \mathrm{~mol} \% \mathrm{Ni} /$ $\mathrm{TiO}_{2}$ and $6 \mathrm{~mol} \% \mathrm{Ni} / \mathrm{TiO}_{2}$, showed the efficiency of 97.65 and $95.69 \%$ under UV light, respectively, which is close to that of pure $\mathrm{TiO}_{2}, 98 \%$, and $9 \mathrm{~mol} \% \mathrm{Ni} / \mathrm{TiO}_{2}$ showed the lowest efficiency of $91.78 \%$. The photodecolorization efficiency of $6 \mathrm{~mol} \% \mathrm{Ni} / \mathrm{TiO}_{2}$ powder showed the highest photocatalytic activity of $96.86 \%$ under visible light as compared to 3 and $9 \mathrm{~mol} \% \mathrm{Ni} / \mathrm{TiO}_{2}$, indicated that as the concentration of $\mathrm{Ni}$ further increased in $\mathrm{TiO}_{2}$, the photocatalytic efficiency is gradually decreased (Ganesh et al. 2012). The photocatalytic efficiency of all prepared samples is given in Table 3.

Higher concentration of $\mathrm{Cu}$ and $\mathrm{Fe}(6$ and $9 \mathrm{~mol} \%$ ) and $\mathrm{Ni}(9 \mathrm{~mol} \%)$ in host $\mathrm{TiO}_{2}$ favored the recombination of electron and hole and covered the active sites on the $\mathrm{TiO}_{2}$ surface, thereby reducing the process. However, when the concentration of metal ion was higher than its optimal level, an excess amount of metal ion could not diffuse into the $\mathrm{TiO}_{2}$ lattice, but deposited on the surface of $\mathrm{TiO}_{2}$ particles. This led to the hindrance of UV light 
penetration reaching the surface of $\mathrm{TiO}_{2}$ which could block the active sites of $\mathrm{TiO}_{2}$. Therefore, this mechanism inhibited the photocatalytic activity (Riaz et al. 2014). On the other hand, it was also reported that as the metal loading increases, agglomeration of metal particles is believed to occur and decrease the photocatalytic activity of the photocatalyst (Yoong et al. 2009). The development of the Schottky barrier in the metal-semiconductor contact region facilitated the separation of charge, thus, improved the photocatalytic efficiency in $3 \mathrm{~mol} \%$ of $\mathrm{Cu}-$ doped $\mathrm{TiO}_{2}$ photocatalyst. The formation of a new energy level in $\mathrm{TiO}_{2}$ due to $\mathrm{Cu}$-doped required the reduction of bandgap and increases the photocatalytic activity over pure $\mathrm{TiO}_{2}$. Since the valence of $\mathrm{Cu}^{2+}, \mathrm{Fe}^{3+}$, and $\mathrm{Ni}^{2+}$ ions are less than that of $\mathrm{Ti}^{4+}, \mathrm{Cu}, \mathrm{Fe}$, and $\mathrm{Ni}$ doping produces oxygen vacancies, which serve as the active sites for water dissociation on the metal-doped $\mathrm{TiO}_{2}$ surfaces. It also catches the holes to limit the recombination of electronhole pairs and to donate in oxidation of organic pollutants (Yang et al. 2015; Zhang et al. 2015).

Doping $\mathrm{TiO}_{2}$ with $\mathrm{Ni}$ introduces a new energy level (Ni impurity level) by the dispersion of metal particles in the $\mathrm{TiO}_{2}$ matrix which acts as an electron trap (Ni et al. 2007). The electron trap will prevent the recombination of electron-hole pairs during the irradiation, thus, increasing the lifetime of charge carriers. Ni-doped $\mathrm{TiO}_{2}$ not only boosts the separation efficiency of photoinduced electrons and holes, but also increases the visible light absorption due to bandgap shifting (Haque et al. 2013). It is well known that in heterogeneous photocatalysis process, the hydroxyl radicals ('OH) are a primary oxidant. When the $\mathrm{TiO}_{2}$ particle absorbs photon energy of equal to or greater than its bandgap, an electron may be promoted from the VB to the $\mathrm{CB}$ leaving behind an electron vacancy or 'hole' in the VB. Likewise, an electron can be transferred from impurity level to $\mathrm{TiO}_{2} \mathrm{CB}$ through the absorption of photon energy equal to or greater than its bandgap. The vacancy created in the impurity band acts as an electron trap. The electron generated in $\mathrm{VB}$ of $\mathrm{TiO}_{2}$ is trapped by the electron trap which reduces the recombination of the electron-hole pairs. If charge separation is maintained, the electron and hole may migrate to the catalyst surface where they participate in redox reactions with sorbed species. Hole $\left(h^{+}\right)$may react with surface-bound $\mathrm{H}_{2} \mathrm{O}$ or $\mathrm{OH}^{-}$to produce the ${ }^{\circ} \mathrm{OH}$ and the electrons $\left(\mathrm{e}^{-}\right)$present at the $\mathrm{CB}$ are scavenged or picked up by $\mathrm{Cu}^{2+}, \mathrm{Fe}^{3+}$, and $\mathrm{Ni}^{2+}$ ions, which then transfer them to the oxygen molecules to form the strong oxidative superoxide radical anion (Haque et al. 2013). These reactive species play an important role in the decolorization of MB (Ali et al. 2017). The increase in photocatalytic activity by increasing $\mathrm{Ni}$ dopant concentration from 3 to $6 \mathrm{~mol} \%$ under visible light may be due to the shifting of the bandgap absorption edge to the visible light region, absorbing the light of longer wavelength. Another explanation for this could be attributed to the fact that $\mathrm{Ni}$-doped $\mathrm{TiO}_{2}$ introduces new trapping sites which affect the lifetime of charge carriers by splitting the time of arrival of photogenerated electrons and holes to reach the photocatalyst surface and, thus, reduce the recombination of electron-hole (Haque et al. 2013).

TABLE 1. Average crystallite size and BET surface area of the prepared photocatalysts

\begin{tabular}{lcc}
\hline \multicolumn{1}{c}{ Photocatalysts } & $\mathrm{d}(\mathrm{nm})$ & Total surface area $\left(\mathrm{m}^{2} / \mathrm{g}\right)$ \\
\hline $\mathrm{Pure} \mathrm{TiO}_{2}$ & 13.42 & 42.08 \\
$3 \mathrm{~mol} \% \mathrm{Cu} / \mathrm{TiO}_{2}$ & 12.75 & 31.13 \\
$6 \mathrm{~mol} \% \mathrm{Cu} / \mathrm{TiO}_{2}$ & 11.77 & 53.09 \\
$9 \mathrm{~mol} \% \mathrm{Cu} / \mathrm{TiO}_{2}$ & 12.12 & 58.83 \\
$3 \mathrm{~mol} \% \mathrm{Fe} / \mathrm{TiO}_{2}$ & 8.52 & 53.34 \\
$6 \mathrm{~mol} \% \mathrm{Fe} / \mathrm{TiO}_{2}$ & 5.91 & 100.21 \\
$9 \mathrm{~mol} \% \mathrm{Fe} / \mathrm{TiO}_{2}$ & 5.70 & 84.50 \\
$3 \mathrm{~mol} \% \mathrm{Ni} / \mathrm{TiO}_{2}$ & 8.27 & 73.18 \\
$6 \mathrm{~mol} \% \mathrm{Ni} / \mathrm{TiO}_{2}$ & 8.28 & 74.12 \\
$9 \mathrm{~mol} \% \mathrm{Ni} / \mathrm{TiO}_{2}$ & 7.03 & 111.30 \\
\hline
\end{tabular}


TABLE 2. Optical properties of pure and $\mathrm{Cu}, \mathrm{Fe}$, and Ni-doped $\mathrm{TiO}_{2}$ photocatalysts

\begin{tabular}{lcc}
\hline \multicolumn{1}{c}{ Photocatalysts } & Bandgap energy $(\mathrm{eV})$ & Absorption edge wavelength $(\mathrm{nm})$ \\
\hline Pure $\mathrm{TiO}_{2}$ & 3.24 & 383 \\
$3 \mathrm{~mol} \% \mathrm{Cu} / \mathrm{TiO}_{2}$ & 3.42 & 363 \\
$6 \mathrm{~mol} \% \mathrm{Cu} / \mathrm{TiO}_{2}$ & 3.38 & 367 \\
$9 \mathrm{~mol} \% \mathrm{Cu} / \mathrm{TiO}_{2}$ & 3.26 & 380 \\
$3 \mathrm{~mol} \% \mathrm{Fe} / \mathrm{TiO}_{2}$ & 3.37 & 368 \\
$6 \mathrm{~mol} \% \mathrm{Fe} / \mathrm{TiO}_{2}$ & 3.38 & 367 \\
$9 \mathrm{~mol} \% \mathrm{Fe} / \mathrm{TiO}_{2}$ & 3.29 & 377 \\
$3 \mathrm{~mol} \% \mathrm{Ni} / \mathrm{TiO}_{2}$ & 3.35 & 370 \\
$6 \mathrm{~mol} \% \mathrm{Ni} / \mathrm{TiO}_{2}$ & 3.35 & 370 \\
$9 \mathrm{~mol} \% \mathrm{Ni} / \mathrm{TiO}_{2}$ & 3.22 & 385 \\
\hline
\end{tabular}

TABLE 3. Decolorization percentage of MB dye under both UV and visible light irradiation

\begin{tabular}{lcc}
\hline \multicolumn{1}{c}{ Photocatalysts } & Efficiency (\%)/UV light & Efficiency $(\%) /$ visible light \\
\hline Pure $\mathrm{TiO}_{2}$ & 98 & 97.26 \\
$3 \mathrm{~mol} \% \mathrm{Cu} / \mathrm{TiO}_{2}$ & 97.65 & 90 \\
$6 \mathrm{~mol} \% \mathrm{Cu} / \mathrm{TiO}_{2}$ & 89 & 55.77 \\
$9 \mathrm{~mol} \% \mathrm{Cu} / \mathrm{TiO}_{2}$ & 81.4 & 64.77 \\
$3 \mathrm{~mol} \% \mathrm{Fe} / \mathrm{TiO}_{2}$ & 96.86 & 84.34 \\
$6 \mathrm{~mol} \% \mathrm{Fe} / \mathrm{TiO}_{2}$ & 94.9 & 60 \\
$9 \mathrm{~mol} \% \mathrm{Fe} / \mathrm{TiO}_{2}$ & 82.38 & 62.42 \\
$3 \mathrm{~mol} \% \mathrm{Ni} / \mathrm{TiO}_{2}$ & 97.65 & 94.32 \\
$6 \mathrm{~mol} \% \mathrm{Ni} / \mathrm{TiO}_{2}$ & 95.69 & 96.86 \\
$9 \mathrm{~mol} \% \mathrm{Ni} / \mathrm{TiO}_{2}$ & 91.78 & 76.90 \\
\hline
\end{tabular}

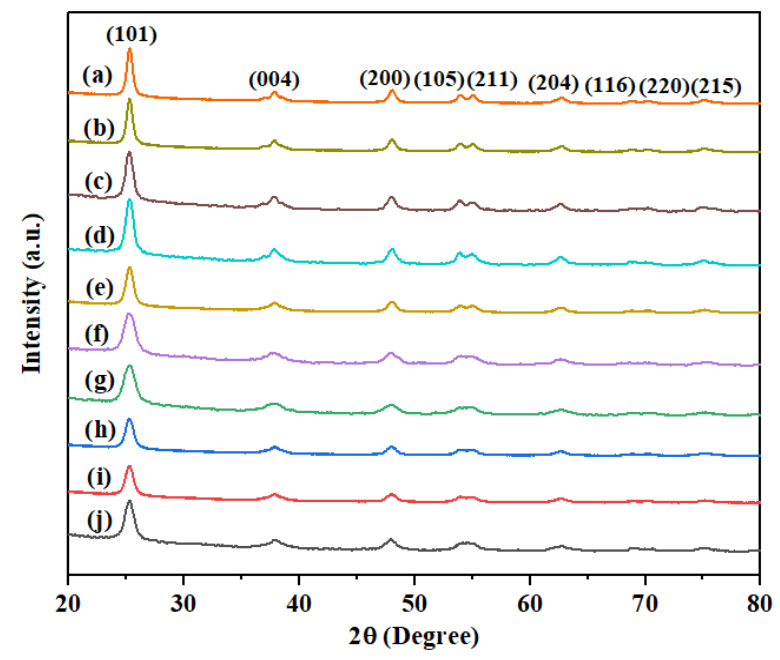

FIGURE 1. X-ray diffraction patterns of (a) pure $\mathrm{TiO}_{2}$, (b) $3 \mathrm{~mol} \% \mathrm{Cu} /$ $\mathrm{TiO}_{2}$, (c) $6 \mathrm{~mol} \% \mathrm{Cu} / \mathrm{TiO}_{2}$, (d) $9 \mathrm{~mol} \% \mathrm{Cu} / \mathrm{TiO}_{2}$, (e) $3 \mathrm{~mol} \% \mathrm{Fe} / \mathrm{TiO}_{2}$, (f) $6 \mathrm{~mol} \% \mathrm{Fe} / \mathrm{TiO}_{2}$, (g) $9 \mathrm{~mol} \% \mathrm{Fe} / \mathrm{TiO}_{2}$, (h) $3 \mathrm{~mol} \% \mathrm{Ni} / \mathrm{TiO}_{2}$, (i) 6 $\mathrm{mol} \% \mathrm{Ni} / \mathrm{TiO}_{2}$, and (j) $9 \mathrm{~mol} \% \mathrm{Ni} / \mathrm{TiO}_{2}$ photocatalysts 


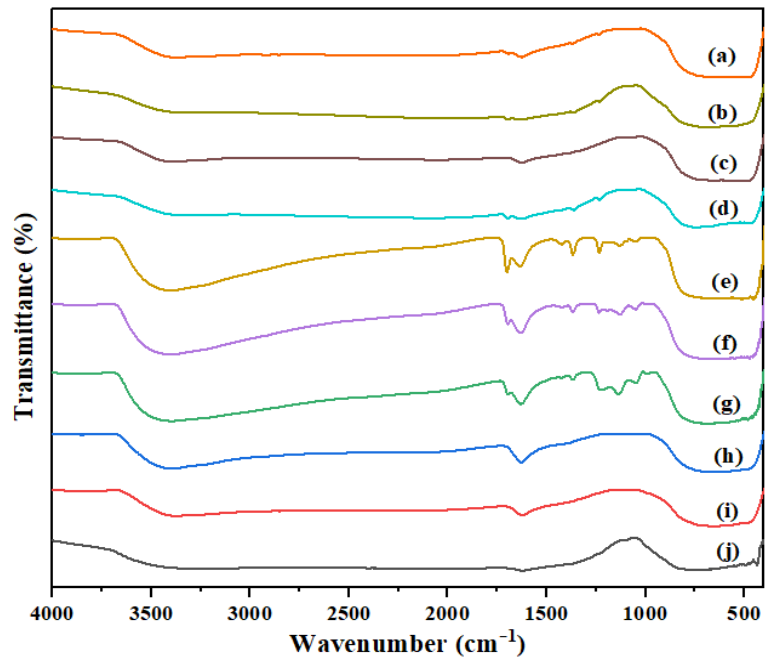

FIGURE 2. FTIR spectra of (a) pure $\mathrm{TiO}_{2}$, (b) $3 \mathrm{~mol} \% \mathrm{Cu} / \mathrm{TiO}$, (c) $6 \mathrm{~mol} \%$ $\mathrm{Cu} / \mathrm{TiO}_{2}$, (d) $9 \mathrm{~mol} \% \mathrm{Cu} / \mathrm{TiO}_{2}$, (e) $3 \mathrm{~mol} \% \mathrm{Fe} / \mathrm{TiO}_{2}$, (f) $6 \mathrm{~mol} \% \mathrm{Fe} / \mathrm{TiO}_{2}$, (g) $9 \mathrm{~mol} \% \mathrm{Fe} / \mathrm{TiO}_{2}$, (h) $3 \mathrm{~mol} \% \mathrm{Ni} / \mathrm{TiO}_{2}$, (i) $6 \mathrm{~mol} \% \mathrm{Ni} / \mathrm{TiO}_{2}$, and (j) 9 $\mathrm{mol} \% \mathrm{Ni} / \mathrm{TiO}_{2}$ photocatalysts
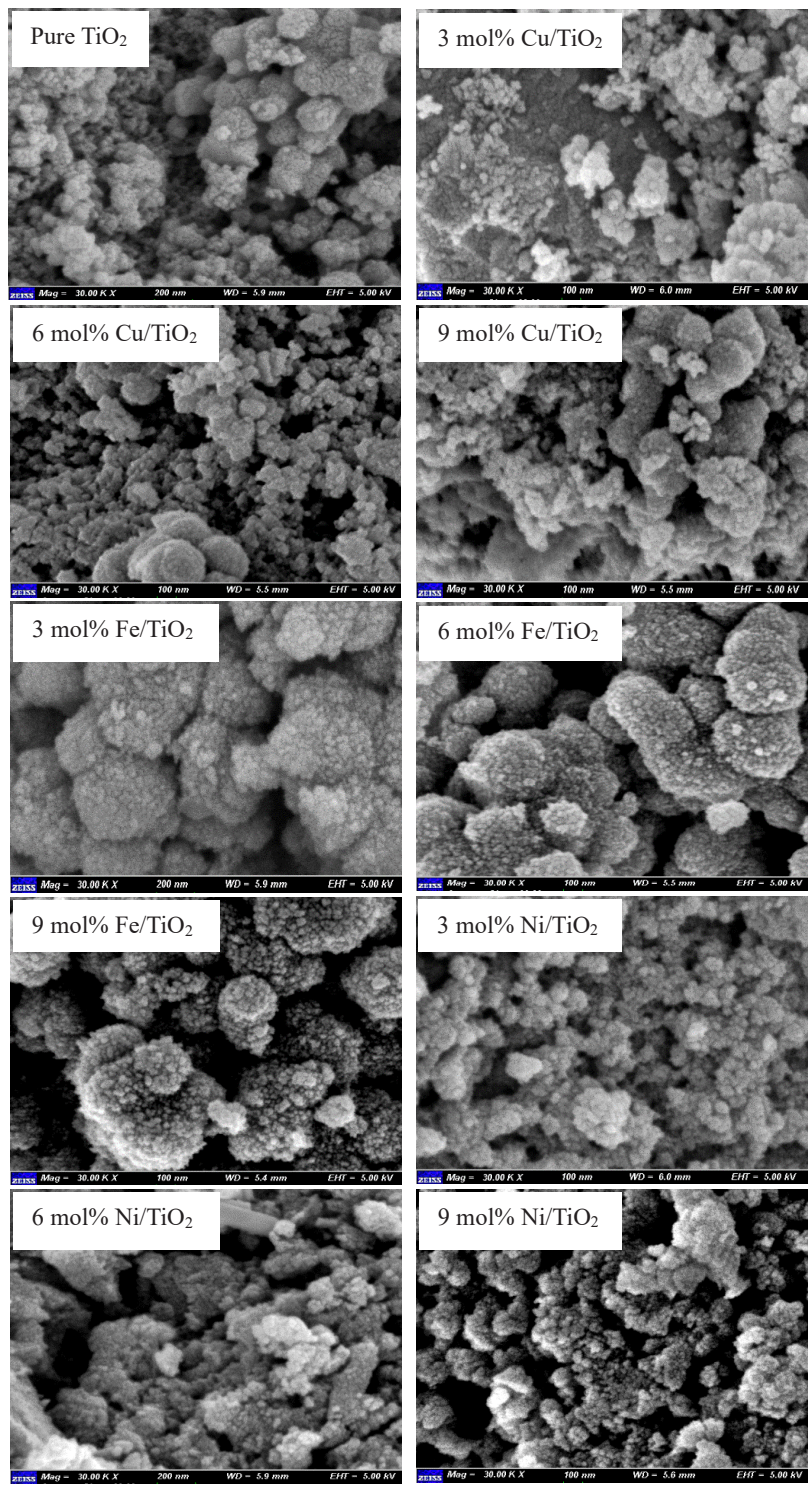

FIGURE 3. FESEM micrographs of pure $\mathrm{TiO}_{2}$ and $\mathrm{Cu}, \mathrm{Fe}$, and Ni-doped $\mathrm{TiO}_{2}$ photocatalysts with different concentration of transition metals 

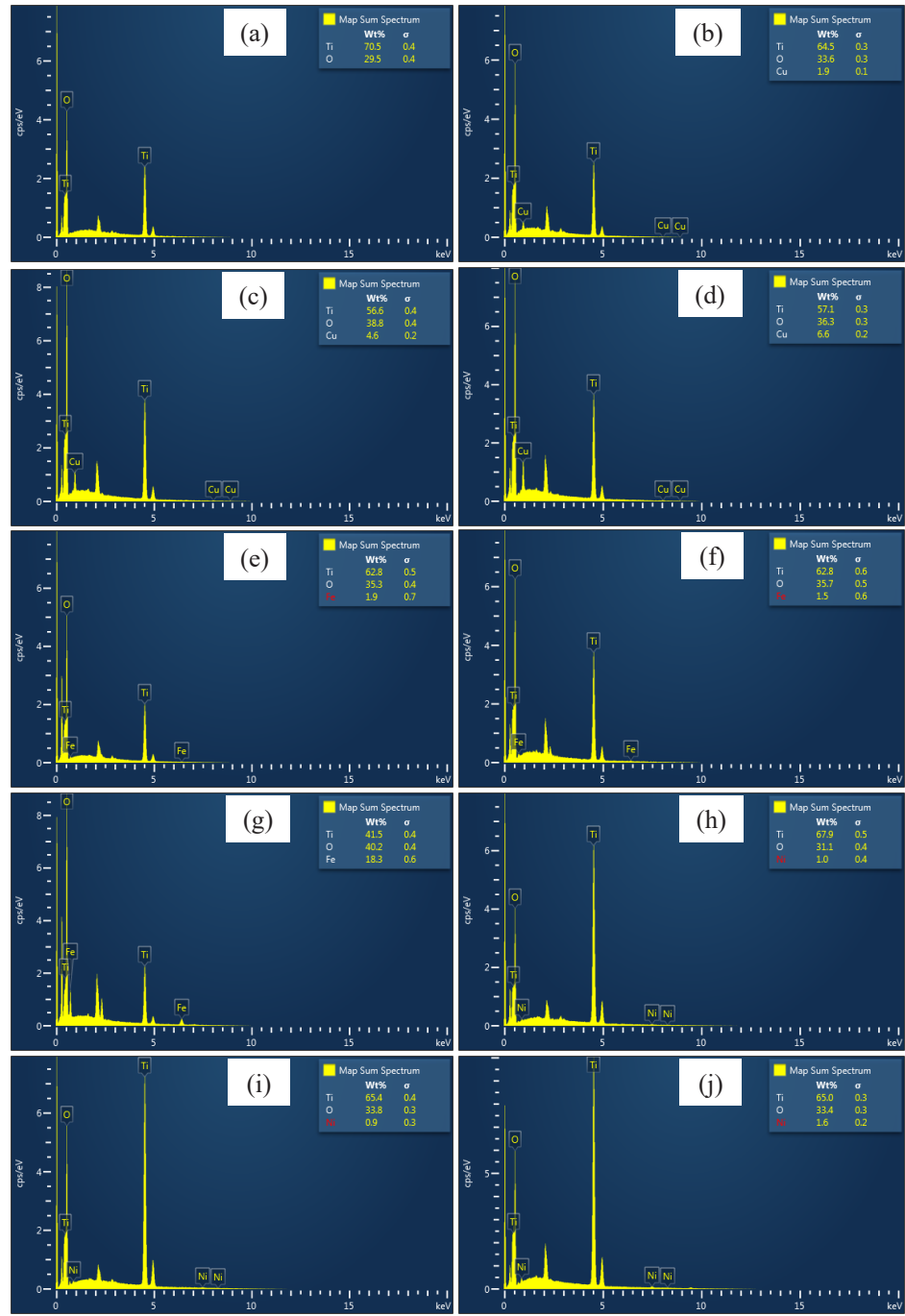

FIGURE 4. FEDX spectra of (a) pure $\mathrm{TiO}_{2}$, (b) $3 \mathrm{~mol} \% \mathrm{Cu} / \mathrm{TiO}_{2}$, (c) $6 \mathrm{~mol} \% \mathrm{Cu} / \mathrm{TiO}_{2}$, (d)

$9 \mathrm{~mol} \% \mathrm{Cu} / \mathrm{TiO}_{2}$, (e) $3 \mathrm{~mol} \% \mathrm{Fe} / \mathrm{TiO}_{2}$, (f) $6 \mathrm{~mol} \% \mathrm{Fe} / \mathrm{TiO}_{2}$, (g) $9 \mathrm{~mol} \% \mathrm{Fe} / \mathrm{TiO}_{2}$, (h) 3 $\mathrm{mol} \% \mathrm{Ni} / \mathrm{TiO}_{2}$, (i) $6 \mathrm{~mol} \% \mathrm{Ni} / \mathrm{TiO}_{2}$, and (j) $9 \mathrm{~mol} \% \mathrm{Ni} / \mathrm{TiO}_{2}$ photocatalysts
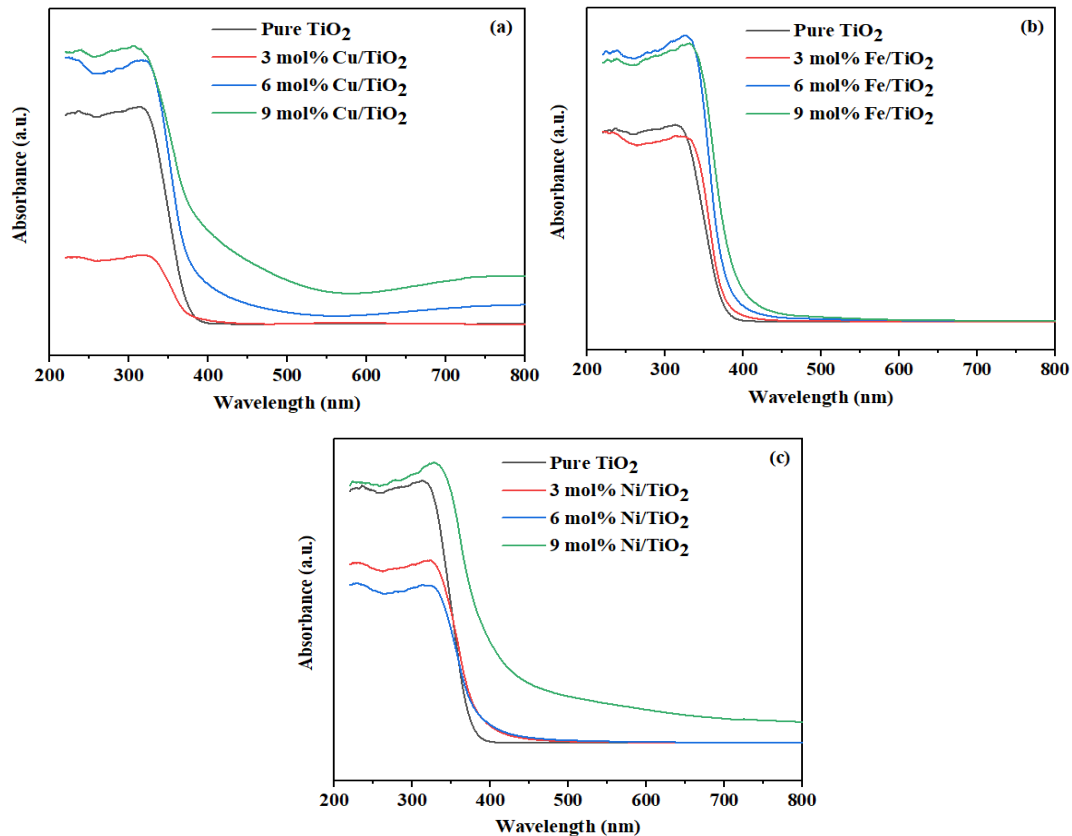

FIGURE 5. UV-Vis absorption spectra of (a) Cu-doped $\mathrm{TiO}_{2}$, (b) Fe-doped $\mathrm{TiO}_{2}$, and (c) Ni-doped $\mathrm{TiO}_{2}$ photocatalysts with different concentration of metals and pure $\mathrm{TiO}_{2}$ is also used as reference

in all cases for comparison with the results obtained 

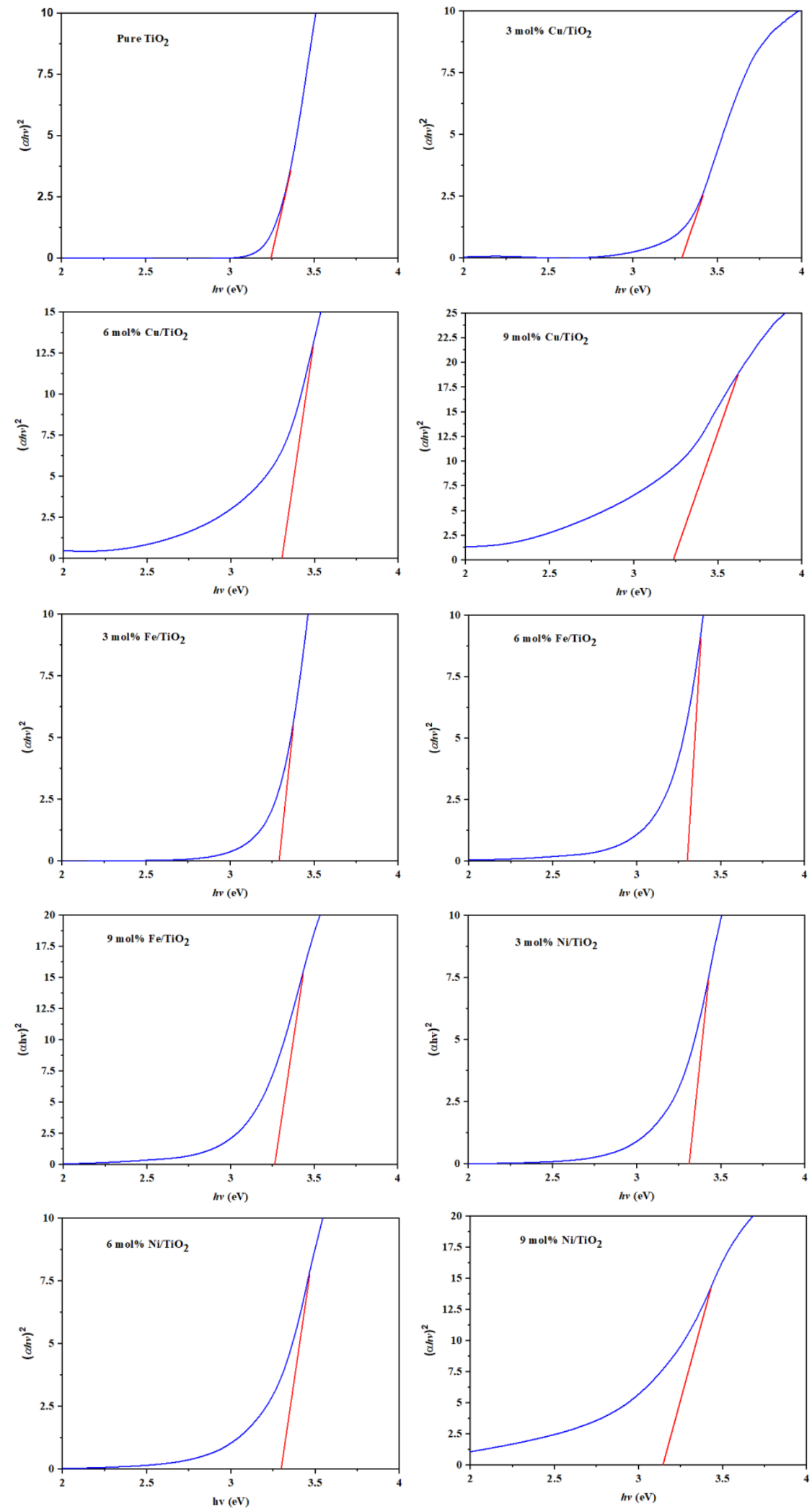

FIGURE 6. Plots of $(\alpha h v)^{2}$ versus $h v$ (Tauc plot) for the estimation of the bandgap energy 

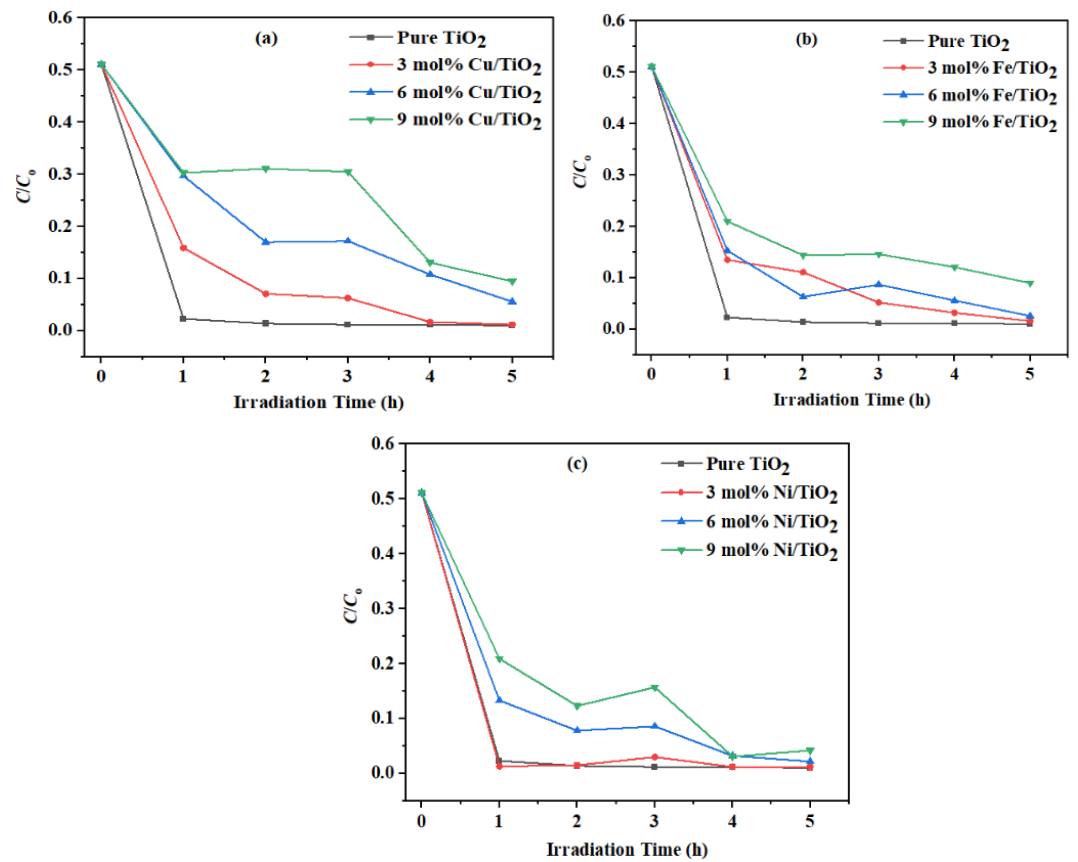

FIGURE 7. The photocatalytic decolorization of MB under UV light irradiation using pure $\mathrm{TiO}_{2}$ and (a) $\mathrm{Cu} / \mathrm{TiO}_{2}$, (b) $\mathrm{Fe} / \mathrm{TiO}_{2}$, and $\mathrm{Ni} / \mathrm{TiO}_{2}$ photocatalysts with different metal concentrations
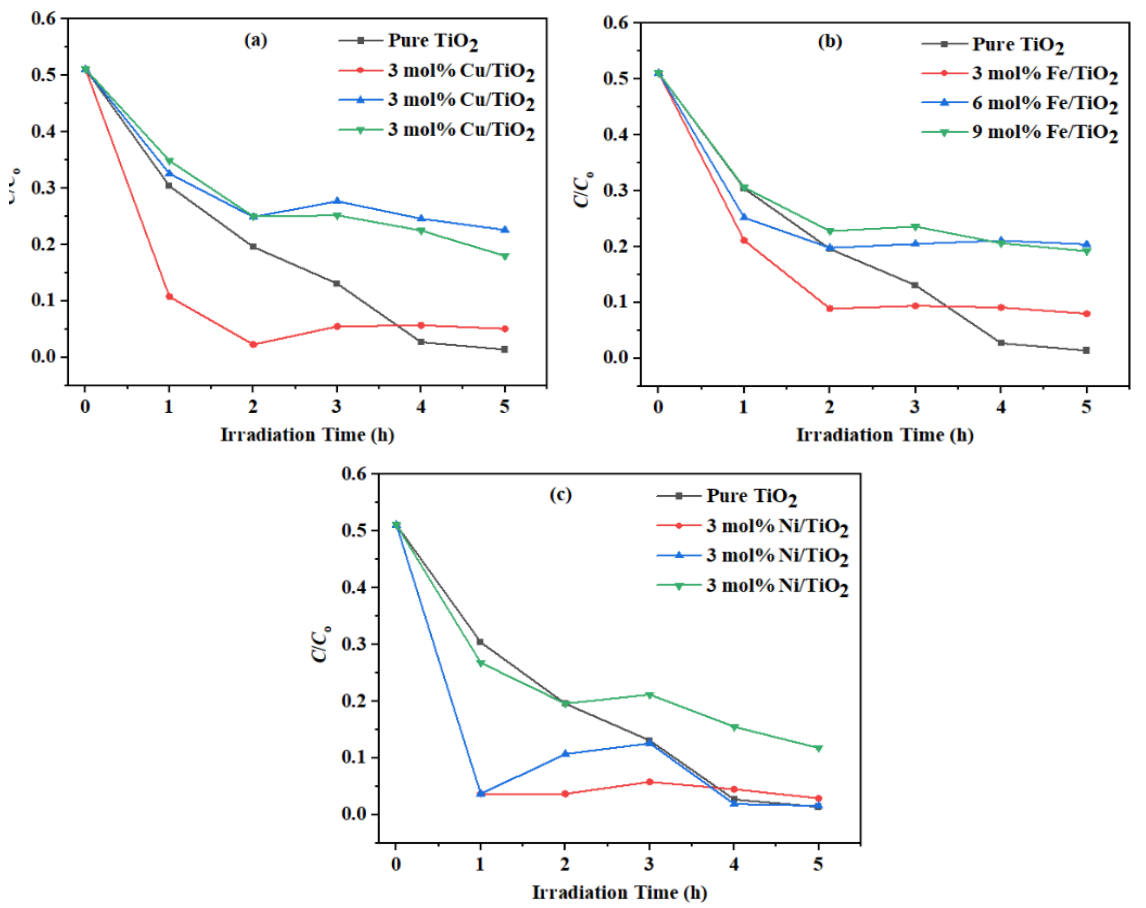

FIGURE 8 . The photocatalytic decolorization of MB under visible light irradiation using pure $\mathrm{TiO}_{2}$ and (a) $\mathrm{Cu} / \mathrm{TiO}_{2}$, (b) $\mathrm{Fe} / \mathrm{TiO}_{2}$, and $\mathrm{Ni} / \mathrm{TiO}$ photocatalysts with different metal concentrations 


\section{CONCLUSION}

In this work, the pure and $\mathrm{Cu}, \mathrm{Fe}$, and $\mathrm{Ni}$-doped $\mathrm{TiO}_{2}$ photocatalysts, were successfully prepared using the solgel method. The XRD patterns of all pure $\mathrm{TiO}_{2}$ and $\mathrm{Cu} /$ $\mathrm{TiO}_{2}, \mathrm{Fe} / \mathrm{TiO}$, and $\mathrm{Ni} / \mathrm{TiO}_{2}$ samples showed the anatase phase structure of $\mathrm{TiO}_{2}$ predominantly and the average crystallite size of the base $\mathrm{TiO}_{2}$ was decreased after doping with transition metals. The presence of strong functional groups on the surface and at the interface of $\mathrm{TiO}_{2}$ particles was showed by FTIR. The FESEM analysis indicated that the particle size of the prepared doped samples was uniform with spherical morphology and their variability was finely tuned with increasing dopant concentration, while EDX results showed that $\mathrm{TiO}$, was successfully incorporated $\mathrm{Cu}, \mathrm{Fe}$, and $\mathrm{Ni}$ metals onto its surface. The BET analysis showed that the specific surface area of pure $\mathrm{TiO}_{2}$ was $42.08 \mathrm{~m}^{2} / \mathrm{g}$ and the surface area of the doped photocatalysts increased with the increasing amount of dopant to $111.3 \mathrm{~m}^{2} / \mathrm{g}$ for $9 \mathrm{~mol} \% \mathrm{Ni}$-doped $\mathrm{TiO}_{2}$ and the pore size of the photocatalysts was confirmed to be in mesoporous region by the BJH method. The optical properties of all samples were carried out using UV-DRS measurements and their obtained bandgap energies were in the range of $3.22-3.42 \mathrm{eV}$. The pure $\mathrm{TiO}_{2}$ photocatalyst displayed more than $98 \%$ and $97 \%$ decolorization rates for MB solution at the end of irradiation time of $5 \mathrm{~h}$ under UV and visible light, respectively. Among all the doped photocatalysts, $3 \mathrm{~mol} \% \mathrm{Ni} / \mathrm{TiO}_{2}$ showed the highest decolorization efficiency of $97.6 \%$ under UV light and $6 \mathrm{~mol} \% \mathrm{Ni} / \mathrm{TiO}_{2}$ photocatalysts showed efficiency of $96.86 \%$ under visible light irradiation in decolorizing MB dye.

\section{ACKNOWLEDGEMENTS}

This work is supported by the UTM Research University Grant via UTM Transdisciplinary Research Grant Scheme (Vot No. 07G30) and Kabul University, Afghanistan for postgraduate scholarship (Jawed Qaderi).

\section{REFERENCES}

Adekoya, D., Tahir, M. \& Amin, N.A.S. 2019. Recent trends in photocatalytic materials for reduction of carbon dioxide to methanol. Renewable and Sustainable Energy Reviews 116: 109389.

Aguilar, T., Navas, J., Alcántara, R., Fernández-Lorenzo, C., Gallardo, J.J., Blanco, G. \& Martín-Calleja, J. 2013. A route for the synthesis of $\mathrm{Cu}$-doped $\mathrm{TiO}_{2}$ nanoparticles with a very low bandgap. Chemical Physics Letters 571: 49-53.

Ahmad, A.L. \& Puasa, S.W. 2007. Reactive dyes decolourization from an aqueous solution by combined coagulation/micellarenhanced ultrafiltration process. Chemical Engineering Journal 132(1-3): 257-265.
Ali, T., Tripathi, P., Azam, A., Raza, W., Ahmed, A.S., Ahmed, A. \& Muneer, M. 2017. Photocatalytic performance of Fe-doped $\mathrm{TiO}_{2}$ nanoparticles under visible-light irradiation. Materials Research Express 4(1): 015022.

Derudi, M., Venturini, G., Lombardi, G., Nano, G. \& Rota, R. 2007. Biodegradation combined with ozone for the remediation of contaminated soils. European Journal of Soil Biology 43(5-6): 297-303.

Edelmannová, M., Lin, K.Y., Wu, J.C., Troppová, I., Čapek, L. \& Kočí, K. 2018. Photocatalytic hydrogenation and reduction of $\mathrm{CO}_{2}$ over $\mathrm{CuO} / \mathrm{TiO}_{2}$ photocatalysts. Applied Surface Science 454: 313-318.

Ganesh, I., Gupta, A.K., Kumar, P.P., Sekhar, P.S.C., Radha, K., Padmanabham, G. \& Sundararajan, G. 2012. Preparation and characterization of Ni-doped materials for photocurrent and photocatalytic applications. The Scientific World Journal 2012: 1-16.

Guo, G., He, C., Wang, Z., Gu, F. \& Han, D. 2007. Synthesis of titania and titanate nanomaterials and their application in environmental analytical chemistry. Talanta 72(5): 1687 1692.

Haque, M.M., Khan, A., Umar, K., Mir, N.A., Muneer, M., Harada, T. \& Matsumura, M. 2013. Synthesis, characterization and photocatalytic activity of visible light induced $\mathrm{Ni}$-doped $\mathrm{TiO}_{2}$. Energy and Environment Focus 2(1): 73-78.

Hu, J., Zhan, L., Zhang, G., Zhang, Q., Du, L., Tung, C.H. \& Wang, Y. 2016. Effects of substitutional dopants on the photoresponse of a polyoxotitanate cluster. Inorganic Chemistry 55(17): 8493-8501.

Inturi, S.N.R., Boningari, T., Suidan, M. \& Smirniotis, P.G. 2014. Visible-light-induced photodegradation of gas phase acetonitrile using aerosol-made transition metal $(\mathrm{V}, \mathrm{Cr}, \mathrm{Fe}$, $\mathrm{Co}, \mathrm{Mn}, \mathrm{Mo}, \mathrm{Ni}, \mathrm{Cu}, \mathrm{Y}, \mathrm{Ce}$, and $\mathrm{Zr}$ ) doped $\mathrm{TiO}_{2}$. Applied Catalysis B: Environmental 144: 333-342.

Jothibas, M., Manoharan, C., Jeyakumar, S.J., Praveen, P., Punithavathy, I.K. \& Richard, J.P. 2018. Synthesis and enhanced photocatalytic property of Ni doped $\mathrm{ZnS}$ nanoparticles. Solar Energy 159: 434-443.

Kavitha, V., Ramesh, P.S. \& Geetha, D. 2016. Synthesis of $\mathrm{Cu}$ loaded $\mathrm{TiO}_{2}$ nanoparticles for the improved photocatalytic degradation of rhodamine B. International Journal of Nanoscience 15(5-6): 1660002.

Kerkez, Ö. \& Boz, İ. 2014. Photo (electro) catalytic activity of $\mathrm{Cu}^{2+}$-modified $\mathrm{TiO}_{2}$ nanorod array thin films under visible light irradiation. Journal of Physics and Chemistry of Solids 75(5): 611-618.

Kerkez-Kuyumcu, Ö., Kibar, E., Dayığlu, K., Gedik, F., Akın, A.N. \& Özkara-Aydınoğlu, Ş. 2015. A comparative study for removal of different dyes over $\mathrm{M} / \mathrm{TiO}_{2}(\mathrm{M}=\mathrm{Cu}, \mathrm{Ni}, \mathrm{Co}, \mathrm{Fe}$, $\mathrm{Mn}$ and $\mathrm{Cr}$ ) photocatalysts under visible light irradiation. Journal of Photochemistry and Photobiology A: Chemistry 311: 176-185.

Krishnakumar, V., Boobas, S., Jayaprakash, J., Rajaboopathi, M., Han, B. \& Louhi-Kultanen, M. 2016. Effect of $\mathrm{Cu}$ doping on $\mathrm{TiO}_{2}$ nanoparticles and its photocatalytic activity under visible light. Journal of Materials Science: Materials in Electronics 27(7): 7438-7447. 
Li, Z., Shen, W., He, W. \& Zu, X. 2008. Effect of Fe-doped $\mathrm{TiO}_{2}$ nanoparticle derived from modified hydrothermal process on the photocatalytic degradation performance on methylene blue. Journal of Hazardous Materials 155(3): 590-594.

Liu, S.X., Chen, X.Y. \& Chen, X. 2007. $\mathrm{A} \mathrm{TiO}_{2} / \mathrm{AC}$ composite photocatalyst with high activity and easy separation prepared by a hydrothermal method. Journal of Hazardous Materials 143(1-2): 257-263.

Manzoor, M., Rafiq, A., Ikram, M., Nafees, M. \& Ali, S. 2018. Structural, optical, and magnetic study of Ni-doped $\mathrm{TiO}_{2}$ nanoparticles synthesized by sol-gel method. International Nano Letters 8(1): 1-8.

Mo, J.H., Lee, Y.H., Kim, J., Jeong, J.Y. \& Jegal, J. 2008. Treatment of dye aqueous solutions using nanofiltration polyamide composite membranes for the dye wastewater reuse. Dyes and Pigments 76(2): 429-434.

Nakhate, G.G., Nikam, V.S., Kanade, K.G., Arbuj, S., Kale, B.B. \& Baeg, J.O. 2010. Hydrothermally derived nanosized Nidoped $\mathrm{TiO}_{2}$ : A visible light driven photocatalyst for methylene blue degradation. Materials Chemistry and Physics 124(2-3): 976-981.

Nankya, R. \& Kim, K.N. 2016. Sol-gel synthesis and characterization of $\mathrm{Cu}-\mathrm{TiO}_{2}$ nanoparticles with enhanced optical and photocatalytic properties. Journal of Nanoscience and Nanotechnology 16(11): 11631-11634.

Thu, T.N.T., Thi, N.N., Quang, V.T., Hong, K.N., Minh, N.T. \& Hoai, N.L.T. 2016. Synthesis, characterisation, and effect of $\mathrm{pH}$ on degradation of dyes on copper-doped $\mathrm{TiO}_{2}$. Journal of Experimental Nanoscience 11(3): 226-238.

Ni, M., Leung, M.K., Leung, D.Y. \& Sumathy, K. 2007. A review and recent developments in photocatalytic watersplitting using $\mathrm{TiO}_{2}$ for hydrogen production. Renewable and Sustainable Energy Reviews 11(3): 401-425.

Rajamannan, B., Mugundan, S., Viruthagiri, G., Praveen, P. \& Shanmugam, N. 2014a. Linear and nonlinear optical studies of bare and copper doped $\mathrm{TiO}_{2}$ nanoparticles via sol gel technique. Spectrochimica Acta Part A: Molecular and Biomolecular Spectroscopy 118: 651-656.

Rajamannan, B., Mugundan, S., Viruthagiri, G., Shanmugam, N., Gobi, R. \& Praveen, P. 2014b. Preparation, structural and morphological studies of Ni doped titania nanoparticles. Spectrochimica Acta Part A: Molecular and Biomolecular Spectroscopy 128: 218-224.

Rauf, M.A. \& Ashraf, S.S. 2009. Fundamental principles and application of heterogeneous photocatalytic degradation of dyes in solution. Chemical Engineering Journal 151(1-3): $10-18$.

Riaz, N., Kait, C.F., Man, Z., Dutta, B.K., Ramli, R.M. \& Khan, M.S. 2014. Visible light photodegradation of azo dye by $\mathrm{Cu} /$ $\mathrm{TiO}_{2}$. Advanced Materials Research 917: 151-159.

Sahoo, C. \& Gupta, A.K. 2015. Characterization and photocatalytic performance evaluation of various metal ion-doped microstructured $\mathrm{TiO}_{2}$ under $\mathrm{UV}$ and visible light. Journal of Environmental Science and Health, Part A 50(7): 659-668.

Sakthivel, T. \& Jagannathan, K. 2017. Structural, optical, morphological and elemental analysis on sol-gel synthesis of $\mathrm{Ni}$ doped $\mathrm{TiO}_{2}$ nanocrystallites. Mechanics, Materials Science \& Engineering Journal 9(1): 2412-5954.
Salehi, M., Hashemipour, H. \& Mirzaee, M. 2012. Experimental study of influencing factors and kinetics in catalytic removal of methylene blue with $\mathrm{TiO}_{2}$ nanopowder. American Journal of Environmental Engineering 2(1): 1-7.

Shehzad, N., Tahir, M., Johari, K., Murugesan, T. \& Hussain, M. 2018. A critical review on $\mathrm{TiO}_{2}$ based photocatalytic $\mathrm{CO}_{2}$ reduction system: Strategies to improve efficiency. Journal of $\mathrm{CO}_{2}$ Utilization 26: 98-122.

Singla, P., Pandey, O.P. \& Singh, K. 2015. Study of photocatalytic degradation of environmentally harmful phthalate esters using Ni-doped $\mathrm{TiO}_{2}$ nanoparticles. International Journal of Environmental Science and Technology 13(3): 849-856.

Sood, S., Umar, A., Mehta, S.K. \& Kansal, S.K. 2015. Highly effective $\mathrm{Fe}$-doped $\mathrm{TiO}_{2}$ nanoparticles photocatalysts for visible-light driven photocatalytic degradation of toxic organic compounds. Journal of Colloid and Interface Science 450: $213-223$

Soutsas, K., Karayannis, V., Poulios, I., Riga, A., Ntampegliotis, K., Spiliotis, X. \& Papapolymerou, G. 2010. Decolorization and degradation of reactive azo dyes via heterogeneous photocatalytic processes. Desalination 250(1): 345-350.

Su, B., Wang, K., Bai, J., Mu, H., Tong, Y., Min, S., She, S. \& Lei, Z. 2007. Photocatalytic degradation of methylene blue on $\mathrm{Fe}^{3+}$-doped $\mathrm{TiO}_{2}$ nanoparticles under visible light irradiation. Frontiers of Chemistry in China 2(4): 364-368.

Vargas, D.X.M., De la Rosa, J.R., Lucio-Ortiz, C.J., HernándezRamirez, A., Flores-Escamilla, G.A. \& Garcia, C.D. 2015. Photocatalytic degradation of trichloroethylene in a continuous annular reactor using $\mathrm{Cu}$-doped $\mathrm{TiO}_{2}$ catalysts by sol-gel synthesis. Applied Catalysis B: Environmental 179: 249-261.

Venkatachalam, N., Palanichamy, M. \& Murugesan, V. 2007. Sol-gel preparation and characterization of nanosize $\mathrm{TiO}_{2}$ : Its photocatalytic performance. Materials Chemistry and Physics 104(2-3): 454-459.

Yang, X.J., Shu, W., Sun, H.M., Wang, X.B. \& Lian, J.S. 2015. Preparation and photocatalytic performance of $\mathrm{Cu}$-doped $\mathrm{TiO}_{2}$ nanoparticles. Transactions of Nonferrous Metals Society of China 25(2): 504-509.

Yoong, L.S., Chong, F.K. \& Dutta, B.K. 2009. Development of copper-doped $\mathrm{TiO}_{2}$ photocatalyst for hydrogen production under visible light. Energy 34(10): 1652-1661.

Zhang, F., Cheng, Z., Kang, L., Cui, L., Liu, W., Xu, X., Hou, G. \& Yang, H. 2015. A novel preparation of Ag-doped $\mathrm{TiO}_{2}$ nanofibers with enhanced stability of photocatalytic activity. RSC Advances 5(41): 32088-32091.

Jawed Qaderi \& Che Rozid Mamat*

Department of Chemistry

Faculty of Science

Universiti Teknologi Malaysia

81310 UTM Johor Bahru, Johor Darul Takzim

Malaysia

Jawed Qaderi

Department of Physical Chemistry

Faculty of Chemistry

Kabul University

Jamal Mina, Kabul

Afghanistan 
Aishah Abdul Jalil

School of Chemical and Energy Engineering Faculty of Engineering

Universiti Teknologi Malaysia

81310 UTM Johor Bahru, Johor Darul Takzim Malaysia

Aishah Abdul Jalil

Centre of Hydrogen Energy

Institute of Future Energy

Universiti Teknologi Malaysia

81310 UTM Johor Bahru, Johor Darul Takzim Malaysia
*Corresponding author; email: cherozid@tm.my

Received: 7 April 2020

Accepted: 23 June 2020 